\begin{abstract}
Iranica
Abstracta Iranica Revue bibliographique pour le domaine irano-aryen

Volume 32-33 | 2013

Comptes rendus des publications de 2009-2010
\end{abstract}

\title{
Ken Parry (ed.). Art, Architecture and Religion Along the Silk Roads
}

\section{Christelle Jullien}

\section{(2) OpenEdition \\ 1 Journals}

\section{Édition électronique}

URL : http://journals.openedition.org/abstractairanica/40864

DOI : 10.4000/abstractairanica.40864

ISSN : 1961-960X

Éditeur :

CNRS (UMR 7528 Mondes iraniens et indiens), Éditions de l'IFRI

\section{Édition imprimée}

Date de publication : 1 décembre 2013

ISSN : 0240-8910

Référence électronique

Christelle Jullien, « Ken Parry (ed.). Art, Architecture and Religion Along the Silk Roads », Abstracta Iranica [En ligne], Volume 32-33 | 2013, document 342, mis en ligne le 01 juillet 2016, consulté le 26

septembre 2020. URL : http://journals.openedition.org/abstractairanica/40864 ; DOI : https://doi.org/ 10.4000/abstractairanica.40864

Ce document a été généré automatiquement le 26 septembre 2020.

Tous droits réservés 


\title{
Ken Parry (ed.). Art, Architecture and Religion Along the Silk Roads
}

\author{
Christelle Jullien
}

\section{RÉFÉRENCE}

Ken Parry (ed.). Art, Architecture and Religion Along the Silk Roads. Turnhout, Brepols, 2009, 308 p. (Silk Road Studies XII)

1 Ce douzième volume de la désormais classique Silk Road Studies constitue les actes de la Conférence tenue en 2004 par la Société australienne pour les études sur l'Asie centrale. Quatorze articles ont été choisis pour cette publication, projet à l'initiative de l'Ancient History Documentary Research Centre de l'Université de Macquarie en Australie. Parmi les domaines représentés par ces contributions, mentionnons en particulier l'art manichéen et bouddhiste, les manuscrits moyen-perses, le christianisme nestorien, sur une aire comprenant notamment la Chine, la Sogdiane et l'ancienne Chorasmie.

2 Table des matières:

3 Part 1: Chorasmia, Sogdia and Uzbekistan

4 - Alison V.G. Betts and V.N. Yagodin, "Tash-k'irman-tepe Cult Complex: an Hypothesis for the Establishment of Fire Temples in Ancient Chorasmia »

5 - Dee Court, « The Ordinary and the Extraordinary in Central Asian Headcoverings »

6 - Fiona Kidd, «The Early Medieval Necropolis at Pap in the Ferghana Valley (Republic of Uzbekistan)»

7 - Michelle Negus-Cleary, "Walls in the Desert: the Phenomenon of Central Asian Urbanism in the Kingdom of Ancient Chorasmia »

Part 2: Christianity and Manichaeism

9 - Samuel Lieu, « Manichaean Art and Architecture along the Silk Road» 
10 - Vladimir Liščák, « Early Chinese Christianity in the Tang Empire: on the Crossroad of two Cultures »

11 - Geoff Watson, «The Ultimate Evangelical away Game: British Missionary Endeavour in Central Asia c. 1830-1930»

12 Part 3: Buddhism and Islam

13 - Mark Allon, «Recent Discoveries of Buddhist Manuscripts from Afghanistan and Pakistan and their Significance »

14 - Ken Parry, «The Buddha as Colossus in Central Asia and China »

15 - Colin Mackerras, «Religion in Contemporary Xinjiang »

16 Part 4: Silk road exchanges

17 - Holly Adams, « Clowns on the Silk Road»

18 - Peter Edwell, «Palmyrene Art, Architecture and Religion on the Euphrates: the Early Evidence for a Palmyrene Community at Dura-Europos ».

\section{AUTEURS}

\section{CHRISTELLE JULLIEN}

CNRS, Mondes iranien et indien, Paris 